\title{
EKSTRAKSI KULIT PETAI SEBAGAI SUMBER ANTIOKSIDAN ALAMI DENGAN METODE DOMESTIC MICROWAVE MACERATION
}

\author{
Agnes, Lois Olivia Widjaja, Aning Ayucitra*, Nani Indraswati \\ Jurusan Teknik Kimia, Fakultas Teknik \\ Universitas Katholik Widya Mandala Surabaya \\ Jalan Kalijudan 37, Surabaya 60114 \\ Email: aayucitra@yahoo.com
}

\begin{abstract}
Abstrak
Penelitian membuktikan bahwa petai (Parkia speciosa) mengandung antioksidan berupa polifenol dan flavonoid yang bisa menangkal radikal bebas dan mampu mencegah bahkan mengatasi beberapa macam penyakit serta dapat berfungsi sebagai penangkap anion superoksida dan lipid superoksida radikal, serta mengurangi aktivitas radikal bebas superoksida. Tujuan dari penelitian ini adalah untuk mempelajari pengaruh perbandingan padatan dan pelarut, konsentrasi etanol, dan waktu radiasi terhadap perolehan dan kadar senyawa fenolik atau Total Phenolic Compound (TPC) ekstrak kulit petai yang diperoleh dengan metode ekstraksi domestic microwave maceration. Mula-mula kulit petai diblender tanpa penambahan air. Proses ekstraksi kulit petai dengan pelarut etanol dilakukan dengan bantuan microwave pada variasi perbandingan padatan dan pelarut, konsentrasi etanol dan waktu radiasi. Setelah itu, padatan dipisahkan dengan pelarutnya. Pelarut diuapkan untuk mendapatkan ekstrak serbuk kulit petai. Ekstrak serbuk kulit petai dianalisis untuk mengetahui perolehan dan TPC. Aktivitas antioksidan ekstrak juga dianalisis dan dinyatakan dalam nilai Inhibisi 50\% ( IC $_{50}$ ). Proses ekstraksi kulit petai yang menghasilkan TPC tertinggi adalah pada perbandingan padatan dan pelarut 1:5, konsentrasi etanol $96 \%$, dan waktu radiasi 150 detik dengan nilai TPC yang diperoleh sebesar 41,43 g GAE (ekivalen asam galat) /100 g ekstrak kulit petai dan $\mathrm{IC}_{50}$ sebesar $364 \mu \mathrm{g} / \mathrm{mL}$.
\end{abstract}

Kata kunci: kulit petai, domestic microwave, antioksidan, fenolik

\begin{abstract}
EXTRACTION OF PETAI PEELS AS NATURAL ANTIOXIDANTS SOURCE BY DOMESTIC MICROWAVE MACERATION. Petai (Parkia speciosa) contains antioxidants that can prevent free radicals. Research also proves that petai is able to prevent and even overcome diseases because its seeds contain polyphenols and flavonoids which are known as antioxidant compounds. Flavonoids may serve as a catcher of superoxide anion and lipid superoxide radicals, and also may reduce the activity of superoxide free radicals. The objective of this research was to study the effects of solid to solvent ratio, ethanol concentration, and radiation time on the yield and Total Phenolic Compound (TPC) of extracts. Petai peels was firstly crushed without the addition of water. Petai peels was then used for extraction process in a domestic microwave. Solid to solvent ratio, ethanol concentration, and radiation time were varied. Following extraction, solvent was separated from the solid and then evaporated. The resulting extract powders were analyzed for yield and TPC. Antioxidant activity of extract was also studied as $\mathrm{IC}_{50}$. As result, petai peels extracted at solid to solvent ratio of $1: 5$, ethanol concentration of $96 \%$, and extraction time of 150 second gave the highest TPC value of 41,43 g GAE /100 g petai peel extracts with IC $_{50}$ of $364 \mu \mathrm{g} / \mathrm{mL}$.
\end{abstract}

Keywords: petai peels, domestic microwave, antioxidants, phenolics

*penulis korespondensi 


\section{PENDAHULUAN}

Petai merupakan salah satu jenis makanan yang disukai oleh masyarakat dan bagian yang dikonsumsi biasanya bagian buah atau biji petai. Kuantitas kulit petai jauh lebih besar dibandingkan dengan bijinya, yaitu sekitar $60-70 \%$ dari berat total buah petai. Biji maupun kulit petai mengandung banyak vitamin, mineral, dan antioksidan, sehingga petai berpotensi sebagai sumber antioksidan alami.

Antioksidan didefinisikan sebagai
senyawa yang dapat menunda, memperlambat, dan mencegah proses oksidasi lipida. Dalam arti khusus, antioksidan adalah zat yang dapat menunda atau mencegah terjadinya reaksi oksidasi radikal bebas dalam oksidasi lipid. Senyawa antioksidan alami umumnya adalah senyawa fenolik atau polifenolik yang dapat berupa golongan flavonoid (Suyoso, 2011). Hampir $80 \%$ dari total antioksidan dalam petai berasal dari flavonoid (Wong dkk., 2006).

Antioksidan dalam kulit petai dapat diperoleh dengan proses ekstraksi. Proses ekstraksi secara umum dapat dilaksanakan dengan cara maserasi, perkolasi, refluks, ekstraksi dengan alat soxhlet, digesti, dan infusa (Ansel, 2008). Pada penelitian ini, senyawa antioksidan diperoleh melalui proses ekstraksi yang mengkombinasikan penggunaan pelarut etanol dan air dibantu dengan gelombang mikro (microwave), yang selanjutnya disebut DMME (Domestic Microwave Maceration Extraction). Metode DMME ini mempunyai keuntungan yaitu waktu ekstraksi yang lebih cepat daripada proses ekstraksi yang lain seperti ekstraksi menggunakan soxhlet.

Dewasa ini, gelombang mikro tidak hanya digunakan pada pengolahan bahan makanan tetapi juga mulai digunakan untuk mengekstraksi bahan aktif tanaman menggantikan teknologi konvensional. Hal tersebut disebabkan gelombang elektromagnetik yang disalurkan melalui radiasi gelombang mikro akan menembus material transparan dan mencapai kelenjar glandular dan sistem vaskuler pada bahan tanaman. Gelombang elektromagnetik ini dapat meningkatkan suhu pelarut dan air yang terkandung di dalam bahan tanaman sehingga dinding sel akan pecah dan zat-zat yang ada di dalam sel tanaman keluar menuju pelarut (Puryani, 2007). Proses ekstraksi dengan bantuan gelombang mikro menjadi lebih efisien dalam hal waktu, dimana dibutuhkan waktu ekstraksi 5 menit jika dibandingkan dengan ekstraksi metode konvensional yang membutuhkan waktu selama 40 menit (Supriyanto dkk., 2006).

Pada proses ekstraksi dengan bantuan gelombang mikro, kadar senyawa fenolik ekstrak yang didapat juga dipengaruhi oleh kemampuan pelarut yang digunakan untuk menyerap energi gelombang elektromagnetik dan mengubahnya menjadi panas yang dinyatakan sebagai faktor disipasi $(\tan \delta$ ). Faktor disipasi menyatakan efisiensi panas yang diterima dari gelombang mikro. Faktor disipasi dipengaruhi oleh nilai kehilangan dielektrik ( $\left.\varepsilon^{\prime \prime}\right)$ yang mengindikasikan efisiensi pelarut dalam mengkonversi energi gelombang elektromagnetik menjadi panas dan nilai konstanta dielektrik $\left(\varepsilon^{\prime}\right)$ yang merupakan ukuran kemampuan pelarut untuk menyerap energi gelombang elektromagnetik (Hartati, 2010). Berdasarkan pada data kehilangan dielektrik $\left(\varepsilon^{\prime \prime}\right)$ dan konstanta dielektrik $\left(\varepsilon^{\prime}\right)$ untuk etanol dan air (Jain dkk., 2009), didapatkan nilai faktor disipasi $(\tan \delta$ ) dari etanol dan air masing-masing sebesar 0,23 dan 0,15 dengan menggunakan persamaan (1).

$\tan \delta=\frac{\varepsilon^{\prime \prime}}{\varepsilon^{\prime}}$

Etanol memiliki harga tan $\delta$ yang lebih besar dibandingkan air sehingga energi gelombang mikro yang terserap oleh pelarut etanol lebih besar dibandingkan air. Energi ini akan menaikkan suhu air yang terkandung di dalam sel kulit petai dan mengubahnya menjadi uap air yang akan menghasilkan tekanan internal di dalam sel kulit petai. Jika tekanan terus membesar maka dinding sel akan membengkak dan akhirnya pecah sehingga senyawa fenolik di dalam sel kulit petai akan terekstrak keluar menuju pelarut (Puryani, 2007).

Pemanfaatan kulit petai untuk bahan antioksidan alami merupakan pemanfaatan limbah yang dapat meningkatkan nilai ekonomis petai sekaligus mengatasi masalah dari penggunaan antioksidan sintetis. Penelitian ekstraksi senyawa antioksidan dari kulit petai biasanya dilakukan dengan metode soxhletasi atau ekstraksi pelarut menggunakan variasi waktu dan suhu ekstraksi. Dari penelitian yang dilakukan oleh Francisco dan Setyo (2011) dengan metode ekstraksi pelarut diketahui bahwa kadar 
senyawa fenolik (TPC) terbesar yaitu $26,42 \mathrm{~g}$ GAE/100 g ekstrak dicapai pada kondisi suhu ekstraksi $80{ }^{\circ} \mathrm{C}$ selama 135 menit. Melalui penelitian ini, diupayakan adanya peningkatan perolehan dan TPC ekstrak kulit petai menggunakan metode DMME (Domestic Microwave Maceration Extraction) yang menggabungkan proses ekstraksi pelarut dan maserasi dengan bantuan gelombang mikro dari alat oven gelombang mikro rumah tangga.

\section{METODE}

Pada prinsipnya, metode DMME (Domestic Microwave Maceration Extraction) merupakan proses ekstraksi dengan maserasi/perendaman disertai radiasi dalam oven gelombang mikro rumah tangga. Oven yang digunakan merupakan peralatan rumah tangga tanpa modifikasi yang memiliki harga lebih murah dan mudah didapatkan di pasaran. Untuk menjaga supaya suhu ekstraksi sekitar $60{ }^{\circ} \mathrm{C}$, maka setiap selang waktu radiasi tertentu campuran padatan dan pelarut dikeluarkan dari oven selama beberapa waktu sambil diaduk.

Proses ekstraksi diawali dengan mencampur kulit petai dengan pelarut, kemudian dimasukkan ke dalam ovengelombang mikro (tipe Inextron WD9000SL23-2 dengan frekuensi $2450 \mathrm{MHz}$, daya keluaran maksimum $900 \mathrm{~W}$, pada pengaturan daya keluaran 20\%) untuk mengalami proses radiasi. Setelah 30 detik, kulit petai dan pelarut dikeluarkan dari oven untuk diaduk dalam shaker selama 2 menit. Selanjutnya, campuran kulit petai dan pelarut diradiasi kembali di dalam oven. Tahapan ini diulang kembali sehingga tercapai waktu radiasi yang diinginkan.

Pada penelitian ini kulit petai diekstraksi menggunakan pelarut etanol dengan berbagai konsentrasi. Proses ekstraksi kulit petai ini menggunakan pelarut air dan etanol karena senyawa fenolik dalam kulit petai sebagian besar berasal dari golongan flavonoid yang memiliki sifat kimia fenol yang larut dalam pelarut polar seperti air dan etanol. Selain itu, pelarut air dan etanol bersifat lebih aman untuk kesehatan dibandingkan pelarut lainnya seperti metanol (Sultana dkk., 2007).

Penelitian ini dibagi menjadi tiga tahap, yaitu: 1) persiapan kulit petai, 2) proses ekstraksi senyawa fenolik dari kulit petai dengan variasi rasio padatan/pelarut, konsentrasi pelarut, dan waktu radiasi, 3) analisis perolehan dan TPC ekstrak kulit petai serta analisis aktivitas antioksidan ekstrak kulit petai dengan TPC tertinggi yang dinyatakan dalam $\mathrm{IC}_{50}$.

Tahap pertama merupakan tahap persiapan bahan baku. Kulit petai yang masih segar diblender tanpa penambahan air. Pada tiap perbandingan padatan/pelarut digunakan volume pelarut yang sama yaitu $100 \mathrm{~mL}$. Massa kulit petai yang digunakan sebesar 6,7 g untuk perbandingan 1/15, $10 \mathrm{~g}$ untuk perbandingan $1 / 10$, dan $20 \mathrm{~g}$ untuk perbandingan 1/5. Tahap kedua adalah proses ekstraksi kulit petai dengan pelarut etanol pada berbagai konsentrasi yaitu 0,48 , dan $96 \%$ berat. Waktu radiasi divariasikan pada 30, 90, dan 150 detik. Setelah itu, padatan dipisahkan dari pelarut, kemudian pelarut diuapkan untuk mendapatkan ekstrak serbuk kulit petai. Ekstrak serbuk kulit petai disimpan dalam lemari es pada suhu $5{ }^{\circ} \mathrm{C}$ untuk digunakan pada tahap selanjutnya.

Pada tahap ketiga, ekstrak serbuk kulit petai dianalisis perolehan kadar senyawa fenolik (TPC) dengan Folin-Ciocalteau dengan spektrofotometri UV-Vis (Shimadzu UV-Vis 1700) pada absorbansi $762 \mathrm{~nm}$ (Mongkolsilp dkk., 2004; Pourmorad dkk., 2006; Waterhouse, 2012). Ekstrak serbuk kulit petai yang mempunyai TPC tertinggi dianalisis aktivitas antioksidannya dengan metode DPPH (1,1-diphenyl-2-picrylhydrazyl) dengan spektrofotometri UV-Vis (Shimadzu UV-Vis 1700) pada absorbansi $514 \mathrm{~nm}$ dan dinyatakan dalam IC $\mathrm{IC}_{50}$ (Molyneux, 2004). Parameter $\mathrm{IC}_{50}$ digunakan untuk menyatakan banyaknya konsentrasi ekstrak kulit petai yang digunakan untuk menghambat aktivitas radikal bebas DPPH sebesar 50\% (Molyneux, 2004). Semakin tinggi kadar senyawa antioksidan dalam sampel maka nilai $\mathrm{IC}_{5} 0$ akan semakin rendah (Mosquera dkk., 2007).

\section{HASIL DAN PEMBAHASAN}

Hasil analisis bahan baku kulit petai sebelum digunakan dalam proses ekstraksi terangkum dalam Tabel 1

Tabel 1. Analisis Bahan Baku Kulit Petai

\begin{tabular}{cc}
\hline Analisis & Nilai \\
\hline Kadar Abu & $1,78 \%$ \\
Kadar Air & $61,3 \%$ \\
TPC (ekstraksi & 44,31 g GAE $/ 100 \mathrm{~g}$ \\
soxhlet) & ekstrak \\
\hline
\end{tabular}


Pengaruh Variabel Percobaan terhadap Perolehan Ekstrak

Perolehan ekstrak merupakan perbandingan dari massa ekstrak yang didapat dari proses ekstraksi dengan massa kulit petai yang digunakan pada proses ekstraksi. Dari Gambar 1-3 diketahui bahwa perolehan ekstrak kulit petai memiliki hasil yang berbeda-beda pada berbagai perbandingan padatan/pelarut, konsentrasi etanol, dan waktu radiasi.

Konsentrasi etanol yang digunakan berpengaruh terhadap perolehan ekstrak. Walaupun hasilnya bervariasi, namun dapat dilihat bahwa semakin tinggi konsentrasi etanol maka perolehan ekstrak yang dihasilkan cenderung semakin rendah. Hal tersebut disebabkan komponen pada kulit petai yang dapat terlarut dalam etanol.

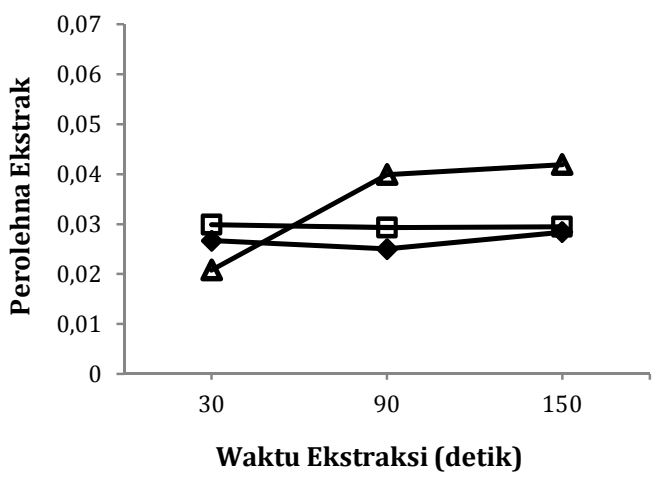

Gambar 1. Perolehan ekstrak kulit petai yang diperoleh pada perbandingan padatan/pelarut $1 / 5$ ( $\bullet$ etanol $0 \%$-b, 口 etanol $40 \%$-b, $\Delta$ etanol $96 \%$-b)

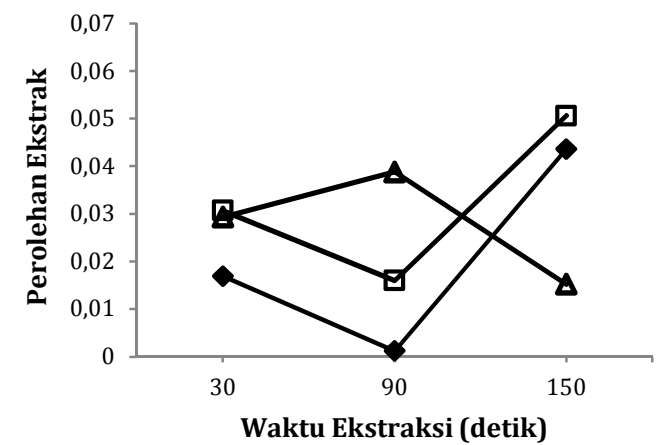

Gambar 2. Perolehan ekstrak kulit petai yang diperoleh pada perbandingan padatan/pelarut $1 / 10$ ( $\bullet$ etanol $0 \%$-b, 口 etanol $40 \%$-b, $\Delta$ etanol $96 \%$-b)

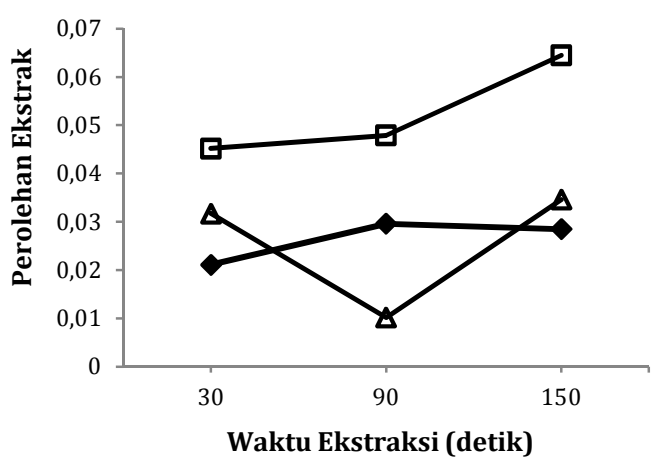

Gambar 3. Perolehan ekstrak kulit petai yang diperoleh pada perbandingan padatan/pelarut $1 / 15$ ( $\diamond$ etanol $0 \%$-b, ㅁ etanol $40 \%$-b, $\Delta$ etanol $96 \%$-b)

Pengaruh waktu radiasi terhadap perolehan ekstrak kulit petai (Gambar 1-3) memiliki hasil yang bervariasi namun sebagian besar dari variasi tersebut memiliki kecenderungan perolehan ekstrak yang lebih banyak dengan waktu radiasi yang semakin lama. Hal tersebut disebabkan karena waktu kontak antara padatan dan pelarut semakin lama sehingga fenolik yang terekstrak juga semakin banyak.

\section{Pengaruh Variasi Percobaan terhadap TPC Ekstrak}

TPC (Total Phenolic Content) menyatakan kadar senyawa fenolik yang terkandung dalam ekstrak kulit petai. Hasil percobaan tentang pengaruh perbandingan padatan/pelarut, konsentrasi etanol, dan waktu radiasi terhadap TPC dapat dilihat pada Gambar 4-6.

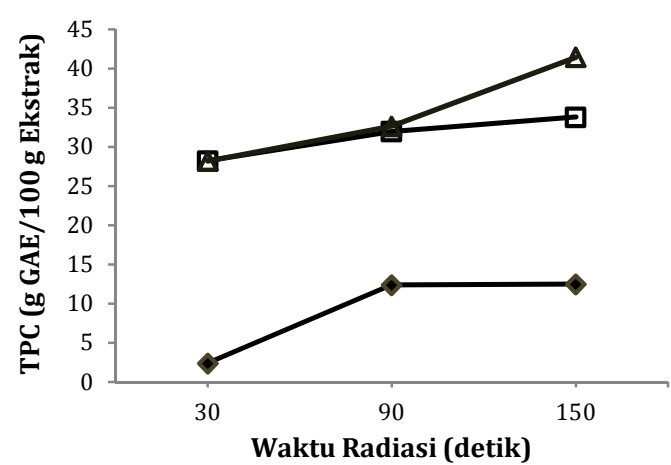

Gambar 4. TPC dalam ekstrak kulit petai pada perbandingan padatan/pelarut 1/5 ( $\bullet$ etanol $0 \%$-b, $\square$ etanol $40 \%$-b, $\Delta$ etanol $96 \%$-b) 


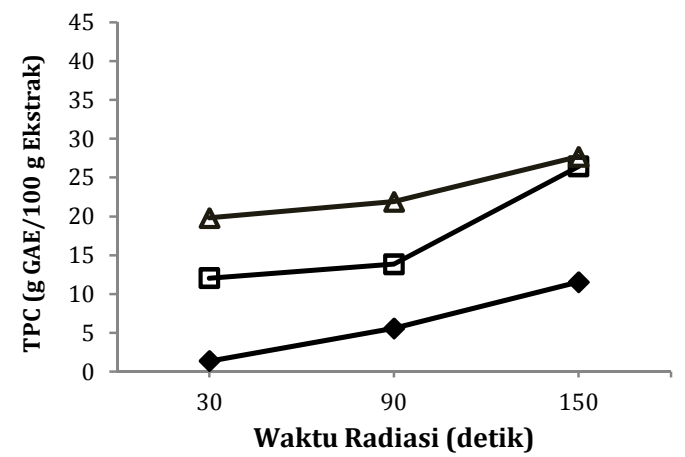

Gambar 5. TPC dalam ekstrak kulit petai pada perbandingan padatan/pelarut 1/10 ( $\bullet$ etanol $0 \%$-b, $\square$ etanol $40 \%$-b, $\Delta$ etanol $96 \%$-b)

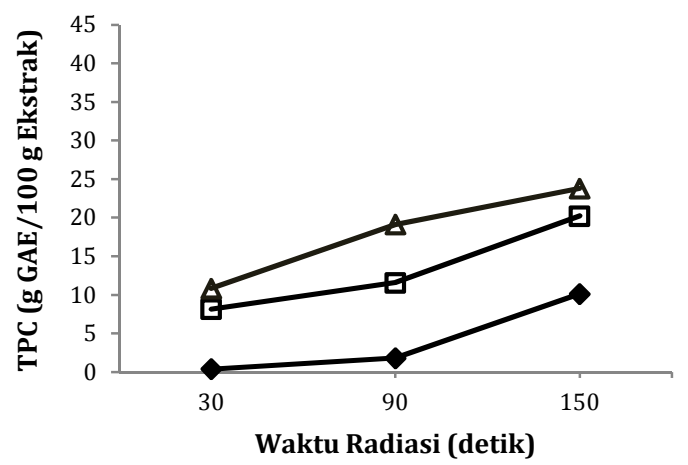

Gambar 6. TPC dalam ekstrak kulit petai pada perbandingan padatan/pelarut 1/15 ( $\diamond$ etanol $0 \%$-b, $\square$ etanol $40 \%$-b, $\Delta$ etanol $96 \%$-b)

Untuk konsentrasi etanol dan waktu radiasi yang sama, proses ekstraksi dengan perbandingan padatan terhadap pelarut $1 / 5$ menghasilkan ekstrak dengan TPC yang paling tinggi. Pada perbandingan padatan /pelarut $1 / 5$, jumlah padatan yang digunakan lebih banyak dibandingkan pada perbandingan padatan/pelarut lainnya sehingga fenolik yang terekstrak lebih banyak.

Pada Gambar 4-6 terlihat bahwa semakin besar konsentrasi etanol maka semakin besar pula TPC yang diperoleh. Hal tersebut disebabkan senyawa fenolik lebih larut dalam etanol sehingga senyawa fenolik yang terekstrak semakin besar jika konsentrasi etanol sebagai pelarut semakin besar. Selain perbandingan padatan/pelarut dan konsentrasi etanol, waktu radiasi juga mempengaruhi TPC dari ekstrak kulit petai. Waktu radiasi yang semakin panjang memberikan waktu yang lebih lama untuk proses perpindahan massa senyawa fenolik dari dalam sel kulit petai menuju pelarut.
Dalam penelitian ini, waktu radiasi dipilih adalah 30, 90, dan 150 detik karena berdasarkan hasil percobaan pendahuluan, waktu radiasi 30 hingga 150 detik terjadi peningkatan TPC, sedangkan waktu radiasi lebih dari 150 detik mulai terjadi penurunan TPC. Hal ini disebabkan karena makin lama waktu radiasi maka energi gelombang mikro yang diserap oleh pelarut maupun kulit petai makin banyak sehingga suhu meningkat dengan cepat. Makin tinggi suhu maka dinding sel akan pecah akibat peningkatan tekanan internal di dalam sel kulit petai sehingga senyawa fenolik di dalam sel kulit petai akan terekstrak keluar menuju pelarut (Puryani, 2007). Akan tetapi, suhu terlalu tinggi dapat menyebabkan senyawa fenolik dalam ekstrak terdegradasi.

\section{Ekstrak Kulit Petai dengan TPC Tertinggi}

Berdasarkan hasil penelitian dengan metode DMME yang telah dilakukan, TPC ekstrak kulit petai yang tertinggi diperoleh pada proses ekstraksi dengan perbandingan padatan / pelarut 1/5, konsentrasi etanol $96 \%$, dan waktu radiasi 150 detik. Pada kondisi tersebut TPC yang didapatkan adalah 41,43 g GAE/100 g ekstrak kulit petai dengan aktivitas antioksidan (dalam $\mathrm{IC}_{50}$ ) sebesar 364 $\mu \mathrm{g} / \mathrm{mL}$. Ekstrak ini memiliki TPC lebih tinggi dan diperoleh dalam waktu lebih singkat daripada ekstrak yang diperoleh oleh Fransisco dan Setyo (2011) dengan metode ekstraksi pelarut, yaitu sebesar 26,42 g GAE/100 g ekstrak kulit petai, dalam waktu 135 menit.

Pada analisis bahan baku kulit petai, dilakukan pengukuran TPC ekstrak kulit petai yang diperoleh melalui metode ekstraksi sohxlet dan didapatkan TPC sebesar 44,31 g GAE/100 g ekstrak. Terlihat bahwa ekstrak yang diperoleh dari metode DMME memiliki TPC 6,5\% lebih kecil dibandingkan dengan TPC ekstrak yang diperoleh dari metode soxhlet.

\section{KESIMPULAN}

Pada penelitian ini, kondisi proses ekstraksi DMME yang menghasilkan ekstrak kulit petai dengan TPC tertinggi $(41,43 \mathrm{~g}$ GAE/100 g ekstrak) yaitu pada perbandingan padatan / pelarut 1/5, konsentrasi etanol 96\%, dan waktu radiasi 150 detik. Aktivitas antioksidan ekstrak tersebut (dinyatakan dalam IC ${ }_{50}$ ) adalah sebesar $364 \mu \mathrm{g} / \mathrm{mL}$. Metode DMME menghasilkan ekstrak kulit 
petai dengan TPC lebih tinggi dalam waktu lebih singkat daripada metode ekstraksi pelarut.

\section{DAFTAR PUSTAKA}

Ansel, H. C., Pengantar Bentuk Sediaan Farmasi, Universitas Indonesia Press: Jakarta, 2008; hlm. 605-619.

Francisco, G.; Setyo, A. D., Pemanfaatan Kulit Petai Sebagai Antioksidan Alami untuk Minyak Goreng Kelapa Sawit, Skripsi Sarjana, Universitas Katolik Widya Mandala Surabaya, Juli 2011.

Hartati, I., Isolasi Alkaloid dari Tepung Gadung Dengan Teknik Ekstraksi Berbantu Gelombang Mikro, Tesis Magister, Universitas Diponegoro, 2010.

Jain, T.; Jain, V.; Pandey, R.; Vyas, A.; Shukla, S. S., Microwave-assisted extraction for phyto constituents-An overview, Asian Journal Research Chemistry, 2009, 2(1), 19-25.

Molyneux, P., The use of the stable free radical diphenylpicrylhydrazyl (DPPH) for estimating antioxidant activity, Songklanakarin Journal of Science and Technology, 2004, 26(2), 211-219.

Mongkolsilp, S.; Pongbupakit, I.; Sae-Lee, N.; Sitthithaworn, W., Radical scavenging activity and total phenolic content of medical plants used in primary health care, SWU Journal of Pharmacy and Science, 2004, 9(1), 32-35.

Mosquera, O. M.; Correa, Y. M.; Buitrago, D. C.; Niño, J., Antioxidant activity of twenty five plants from Colombian biodiversity, Memórias do Instituto Oswaldo Cruz, 2007, 102(5), 631634.
Pourmorad, F.; Hosseinimehr, S. J.; Shahabimajd, N., Antioxidant activity, phenol and flavonoid contents of some selected Iranian medicinal plants, African Journal of Biotechnology, 2006, 5(11), 1142-1145.

Puryani, Aplikasi Gelombang Mikro (Microwave Oven) dan Gelombang Ultrasonik Sebelum Proses Maserasi Buah Vanili (Vanili Planifolia Andrews) Hasil Modifikasi Proses Kuring, Skripsi Sarjana, Institut Pertanian Bogor, 2007.

Sultana, B.; Anwar, F.; Przybylski, R., Antioxidant potential of corncob extracts for stabilization of corn oil subjected to microwave heating, Food Chemistry, 2007, 104(3), 997-1005.

Supriyanto; Haryadi; Rahardjo, B.; Marseno, D. W., Aktivitas antioksidan ekstrak polifenol kasar dari kakao hasil penyangraian menggunakan enerji gelombang mikro, Jurnal Teknologi dan Industri Pangan, 2006, 17(3), 176-182.

Suyoso, H. C., Uji Aktivitas Antioksidan Dan Identifikasi Senyawa Aktif Ekstrak Tanaman Anting-Anting (Acalypha indica L.), Tugas Akhir Sarjana, Universitas Islam Negeri Maulana Malik Ibrahim, 2011.

Waterhouse, A., Folin-Ciocalteau Micro Method for Total Phenol in Wine, Department of Viticulture \& Enology University of California Davis, 1999, http://waterhouse.ucdavis.edu /faqs/folin-ciocalteau-micro-method-for-total -phenol-in-wine (akses 7 Agustus 2012).

Wong, S. P.; Leong, L. P.; Koh, J. H. W., Antioxidant activities of aqueous extracts of selected plants, Food Chemistry, 2006, 99(4), 775-783. 